\title{
Growth and development of Gnathostoma spinigerum (Nematoda: Gnathostomatidae) larvae in Mesocyclops aspericornis (Cyclopoida: Cyclopidae)
}

\author{
Penchom Janwan ${ }^{1,2}$, Pewpan M Intapan ${ }^{1,2}$, Oranuch Sanpool ${ }^{1,2}$, Luxkhana Sadaow ${ }^{1,2}$, Tongjit Thanchomnang ${ }^{2,3}$ \\ and Wanchai Maleewong ${ }^{1,2^{*}}$
}

\begin{abstract}
Background: Gnathostoma spinigerum larva is pathogenic, causing gnathostomiasis in humans and certain animals, and is prevalent mainly in Asia. Growth and development of Gnathostoma spinigerum larvae in the cyclopoid copepod Mesocyclops aspericornis, the first intermediate host, were examined.

Results: When newly hatched, ensheathed second-stage larvae (L2) were ingested by M. aspericornis, they immediately appeared exsheathed in the stomach of M. aspericornis. They then penetrated the stomach wall and entered the body cavity, where they immediately metamorphosed to a stunted form with the body length/width ratio equal to the early third-stage larvae (EL3) up to $2 \mathrm{~h}$ after being ingested. During metamorphosis, the anterior spine-like structure of L2 transformed into unequal transparent lips. The larvae moulted into EL3 in the body cavity of the copepod at around day 5-7 post-infection. Minute cuticular striations were seen on the whole body, with prominent single-pointed spines on the anterior part of the body. The head bulb had four rows of hooklets and two lateral trilobed lips. The size of EL3 in copepods continuously increased towards day 12 and showed a negative correlation to their density per copepod $(R=-0.881, P<0.05$ for body length, and $R=-0.906, P<0.05$ for body width).

Conclusions: The results revealed for the first time that $M$. aspericornis, one of the most abundant freshwater copepods in Thailand, is a suitable first intermediate host for G. spinigerum. High susceptibility of M. aspericornis suggests its importance for the maintenance of the life cycle of G. spinigerum in Thailand.
\end{abstract}

\section{Background}

Gnathostoma spinigerum is a nematode parasite mostly found in the stomach wall of canine and feline definitive hosts. Gnathostoma spinigerum larvae are also pathogenic, causing gnathostomiasis in humans and certain animals, and is prevalent mainly in Asia [1,2]. The life cycle of G. spinigerum has been previously reported $[1,2]$. When eggs passed in feces reach freshwater, the second-stage (L2) larvae develop in ovo within one week, hatch from eggs, and begin swimming freely. Once L2 are eaten by cyclopoid copepods, the larvae

\footnotetext{
* Correspondence: wanch_ma@kku.ac.th

'Department of Parasitology, Faculty of Medicine, Khon Kaen University, Khon Kaen 40002, Thailand

Full list of author information is available at the end of the article
}

cast their sheath and develop into complete L2 and early third-stage larvae (EL3). When the infected copepods are ingested by various intermediate/paratenic hosts - e.g. fishes, amphibians, reptiles, etc, the larvae develop further to become advanced third-stage larvae (AL3), which infect the definitive hosts. When AL3 are ingested by the definitive hosts, they migrate further into the host tissue and finally develop into the adult stage in the stomach wall to complete their life cycle. Cyclopoid copepods, thus, play a crucial role in maintain the life cycle of G. spinigerum. In Thailand, 4 species of cyclopoid copepods, Mesocyclops leuckarti, Eucyclops agilis, Cyclops varicans, and Thermocyclops sp. were proven experimentally as the first intermediate host for G. spinigerum [3]. Here, we report for the first time that

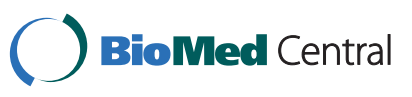

(c) 2011 Janwan et al; licensee BioMed Central Ltd. This is an Open Access article distributed under the terms of the Creative Commons Attribution License (http://creativecommons.org/licenses/by/2.0), which permits unrestricted use, distribution, and reproduction in any medium, provided the original work is properly cited. 
G. spinigerum can develop into EL3 in M. aspericornis, the pantropical freshwater cyclopoid copepod widely spread in Asia, America and Africa [4-6], and is abundant in Thailand [7]. High susceptibility of Mesoycyclops suggests its importance for the maintenance of the life cycle of G. spinigerum in Thailand.

\section{Methods}

\section{Parasite}

Eggs of G. spinigerum were collected from the stools of experimentally infected dogs by a brine floatation method [8]. Each animal was housed in a kennel $(6.5 \times$ $6.5 \mathrm{~m}^{2} / \mathrm{dog}$ ) with a concrete floor and wooden stand for rest; it was cleaned daily with a high-pressure cleaner. Dogs were fed with commercially prepared dry dog food and had access to tap water ad libitum. The study was carried out at the experimental unit of the Faculty of Medicine, Khon Kaen University (Khon Kaen, Thailand). After extensive washing, eggs were suspended in freshwater and incubated at $27 \pm 2^{\circ} \mathrm{C}$ (mean $\pm \mathrm{SD}$ ). Development of embryonated eggs was regularly monitored. After hatching, L2 were collected for experimental infection to copepods. The study protocol was approved by the Animal Ethics Committee of Khon Kaen University, based on the Ethics of Animal Experimentation of the National Research Council of Thailand (Reference no.0514.1.12.2/1).

\section{Mass rearing of cyclopoid copepods}

Copepods were collected from their natural breeding site at Muang district, Khon Kaen province in northeastern Thailand and were identified as $M$. aspericonis by using the descriptions and keys of Van de Velde [4]. Several isofemale lines were established from gravid females and maintained in the Department of Parasitology, Faculty of Medicine, Khon Kaen University. Gravid female $M$. aspericornis from different isofemale lines were massreared in dechlorinated water in $1 \mathrm{~L}$ beakers $(15$ isofemale lines/beaker) at $27 \pm 2^{\circ} \mathrm{C}$. Paramecium spp., cultured in boiled rice straw water extract, and commercial powdered fish food were used to nourish the copepods.

\section{Experimental infection of copepods with G. spinigerum larvae}

M. aspericornis, 14-day-old, were placed in clean 600-ml beakers containing $250 \mathrm{ml}$ dechlorinated water (80 copepods/beaker). They were divided into three duplicate groups, and each duplicate group was fed with 400, 700 and 1,200 G. spinigerum L2. The experiment was terminated $12 \mathrm{~d}$ after infection.

\section{Development of $G$. spinigerum larvae in copepods}

Infected copepods were sampled and dissected under a stereomicroscope. Body length and width of G. spinigerum
L2 and EL3 were measured daily up to day12 post-infection (PI). All recovered larvae were photographed under a microscope (Olympus BX51, Tokyo, Japan). Worm length and width were determined using a DP2-BSW XV image processing program (Olympus) and calibrated with the stage micrometer. Body length was measured from the head lip to the end of the tail, while body width was measured at the esophageal-intestinal junction. To explore the density effect of EL3 on their infectivity, the large EL3 were recovered from copepods harboring only 1 larva, whereas the small EL3 were recovered from copepods harboring 13 larvae on day 12 PI. They were separately fed to mice orally (15 EL3/mouse; 6 mice/group). All mice were killed by ether inhalation on day $30 \mathrm{PI}$ and dissected. All organs were examined under a dissecting microscope (14$45 \times$ ) for AL3 by compression method, and the mean number and size of AL3 from each group were determined.

\section{Statistical analysis}

Results were analyzed statistically by Student's $t$-test or Mann-Whitney rank sum test, as appropriate; a $P$ value less than 0.05 was considered significant. Correlations were analyzed using Spearman's rank correlation test.

\section{Results}

Development of G. spinigerum larvae in copepods

Growth and development of newly hatched G. spinigerum larvae in $M$. aspericornis was monitored immediately after ingestion up to day $12 \mathrm{PI}$. The chronological changes of the body sizes are summarized in Figure 1. The newly hatched L2 was slender filariform about $18 \times$ $360 \mu \mathrm{m}$ (width $\times$ length) and were enclosed in a delicate, smooth, transparent sheath. The round anterior head was armed with a minute, solid spine-like structure.

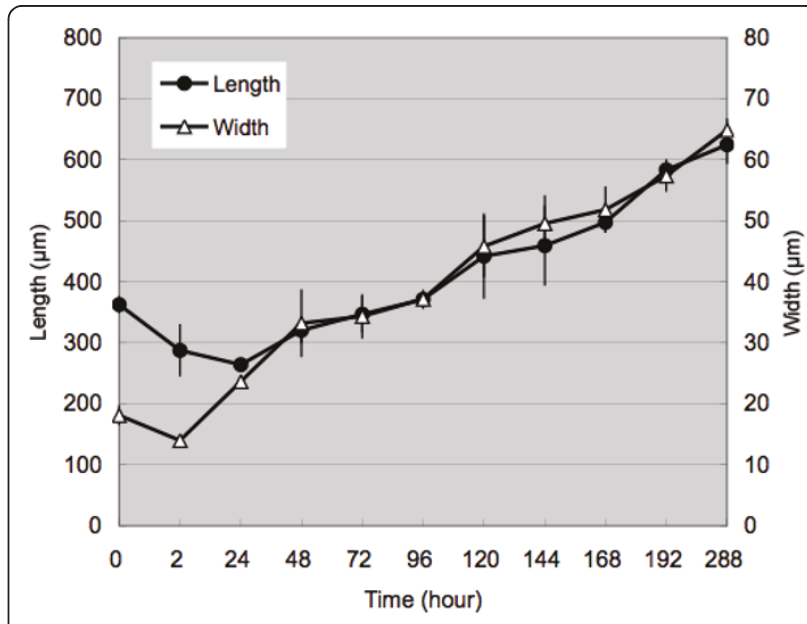

Figure 1 Chronological changes of body sizes. The chronological changes of Gnathostoma spinigerum body sizes in Mesocyclops aspericornis. 
Immediately after being ingested by copepods, the larvae exsheathed to become the complete L 2 with the reduced size. Two small transparent unequal lips developed at the head of L2 at around 1 h PI. L2 in the stomach of copepods further reduce their size measuring about $14 \times 280 \mu \mathrm{m}$ at $2 \mathrm{~h} \mathrm{PI}$. Then they penetrated across the stomach wall to lodge in the body cavity of copepods by $24 \mathrm{~h}$ PI where they started to increase in width but further reduce in length slightly, measuring about $24 \times 264 \mu \mathrm{m}$. At this stage, granulated cells were observed in the gut lumen of L2. Hereafter, the body width:length ratio remained about 1:10, regardless of L2 or EL3 stages.

On day 2 PI, the overall size of larvae increased $(33 \times$ $320 \mu \mathrm{m})$, and early development of cervical sacs was seen. On day 3 , the body size increased further $(34 \times 346$ $\mu \mathrm{m})$, and the esophagus and intestine became visible. On days 4-5 PI, the larvae showed continuous growth and the cells of cervical sacs, esophagus and intestine were distinctly seen. On day $5 \mathrm{PI}$, transverse striations of the body cuticle and head bulb were formed. Some larvae showed a molting cuticle (sheath) extending slightly beyond the head and tail ends (Figure 2).

On day 6 , the larvae further increased in size $(50 \times$ $460 \mu \mathrm{m})$, and the majority of larvae exsheathed to become early third-stage larvae (EL3). Minute cuticular striations were observed over whole body with prominent single-pointed spines on the anterior part of the body. Two lateral trilobed lips were symmetrically formed. The head bulb had four rows of hooklets. Cervical glands and four cervical sacs were distinctly formed;

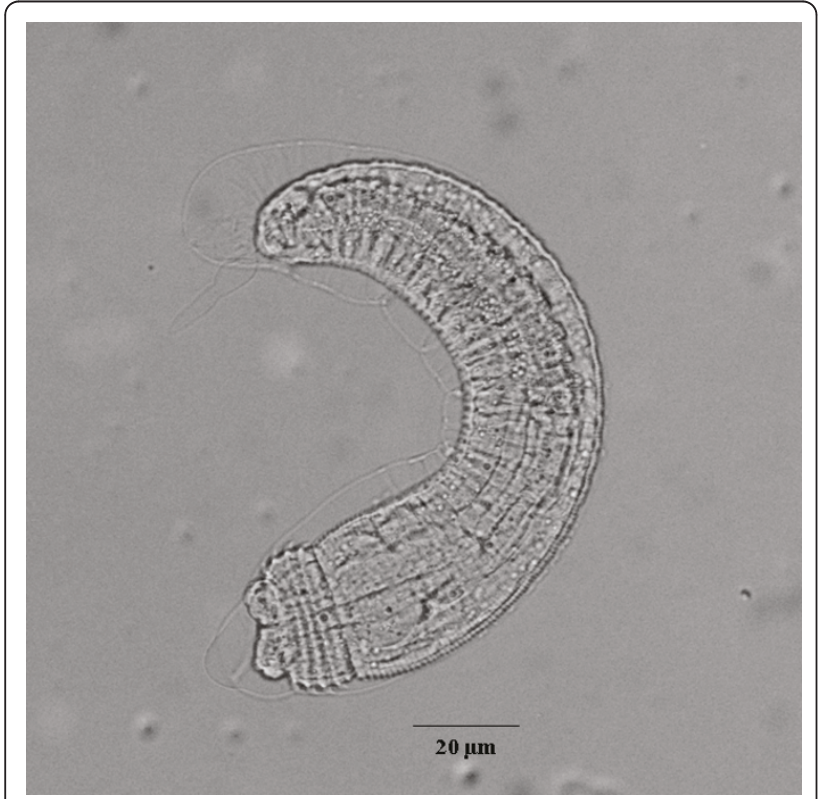

Figure 2 Five-day-old G. spinigerum larva. The molted cuticle extending slightly beyond the head and tail ends. the esophagus, intestine and anus were also welldefined. The posterior end of the larval worm was round in shape. The undifferentiated genital primordium was located near the esophageal-intestinal junction. All these features are characteristic of EL3.

On day 7 PI, all larvae examined were exsheathed. EL3 showed sluggish movement within the body cavity of copepods (See additional File 1). On days 8-12, the larvae did not show any significant morphological transformation but consistently increased their sizes. On day 12 PI, they measured $65 \times 625 \mu \mathrm{m}$.

\section{Density effect on the growth/development of larvae}

All infected copepods were dissected on day 12 PI. The intensity of infection per copepod ranged from 1 to 13 . Mean $( \pm S D)$ body length and width of EL3 in relation to the number of larvae per copepod are shown in Figure 3. A negative relationship $(\mathrm{R}=-0.881, P<0.05$ for body

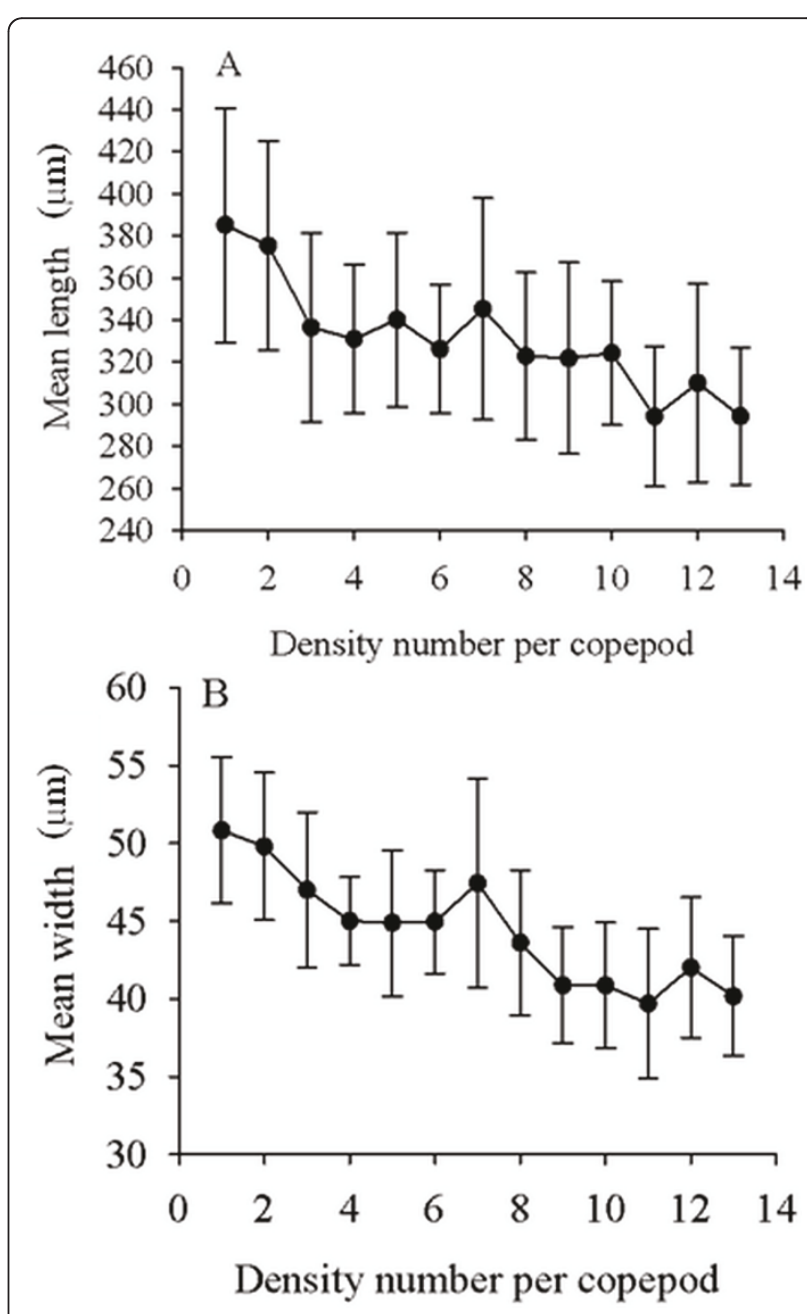

Figure 3 Relationship of worm size and density per copepod. The relationship of worm size and density per copepod: $\mathbf{A}$, length; B, width. 
length, and $\mathrm{R}=-0.906, P<0.05$ for body width) was observed between the mean length and width of EL3 and the density of larvae in copepods.

To see whether the initial size of EL3 would affect the subsequent growth/development to the advanced thirdstage larvae (AL3) in mammalian hosts, the small larvae collected from heavily infected copepods (13 EL3/copepod) and the large larvae collected from copepods having single EL3 were separately infected in mice (15 EL3/mouse for both group) and the AL3 were recovered on day $30 \mathrm{PI}$. The results were summarized in Table 1. For both groups of mice given small or large AL3, the mean number \pm SD of worm recovery per mouse were $5.50 \pm 1.04$ and $5.67 \pm$ 1.21 , respectively $(P>0.05)$. Approximately $40 \%$ of EL3 developed into AL3 in both groups. The body length and width of AL3 descended from small and large EL3 from copepods were also not significantly different regardless of the size of the ancestral EL3 (Table 1).

\section{Discussion}

In this study, we extensively observed the growth and development of G. spinigerum larvae in a first intermediate host, the copepod $M$. aspericornis. Previously M. leuckarti, E. agilis, E. serrulatus, C. varicans, C. strenuus, $C$. vicinus and Thermocyclops sp. $[1,3,9,10]$ have been proven as experimental first intermediate hosts for G. spinigerum larvae. Our results revealed for the first time that $M$. aspericornis, one of the most abundant freshwater copepods [4-6] - especially in Thailand [7] is also a suitable first intermediate host for G. spinigerum. To our knowledge, Gnathostoma larvae have never been found in any copepod species in the wild. $M$. aspericornis should be included as a potential candidate of the natural first intermediate hosts for G. spinigerum.

Mesocyclops aspercornis is a cyclopoid copepod abundant in Afro-Asian continents [4-6]. Moreover, this species has been artificially propagated to control mosquito larvae in natural freshwater reservoirs in the dengue vector control program in various countries [11-13] including Thailand [7]. Such an artificial expansion of Mesocyclops might cause contamination of natural water reservoirs and would cause acceleration of the G. spinigerum life cycle or create new endemic areas of gnathostomiasis. From a public health point of view, the prevalence of $G$. spinigerum larvae in fish and the human habits of consuming raw or undercooked fish should be examined before introduction of the mosquito control programs by Mesocyclops to avoid possible outbreaks of gnathostomiasis.

In the present study, the growth/development of $G$. spinigerum larvae in $M$. aspericornis were basically identical to that reported by Miyazaki [1,9], and similar to that reported for other species, i.e. G. binucleatum [14], G. turgidum [15], G. hispidum [3,16,17], G. nipponicum [18], and G. procyonis [19]. While the first molt from first-stage larvae to L2 occurred in eggs, L2 showed considerable reduction of body size and morphological changes during the first $2 \mathrm{~h}$ in copepods. The second molt from L2 to L3 required a longer incubation period, occurring at around days 5-7 PI and the body size continuously increased even during molting.

On day 12 PI, a negative relationship was observed between the density and the size of larvae in copepods. Density-dependent growth/development can occur at each stage of the parasite life cycle $[20,21]$ and various model systems have been reported to investigate this phenomenon; Trichostrongylus retortaeformis infection in rabbits [22]; Maritrema novaezealandensis in amphipod hosts [23]; Pomphorhynchus laevis in their amphipod intermediate hosts Gammarus pulex [24]. Shostak et al. [25] revealed a density-dependent reduction of the body size of the tapeworm Triaenophorus crassus procercoid in the copepod Cyclops bicuspidatus thomasi, and explained this phenomenon by the limitation of the host size. However, in the present study, the sizes of AL3 descended from small and large EL3 from copepods were not significantly different regardless of the size of the ancestral EL3. This result should be further investigated. In addition, G. spinigerum larvae in the first intermediate host copepod can serve as a possible model that provides a better understanding of the ecological relationship between parasites and hosts.

\section{Conclusions}

Our results revealed for the first time that $M$. aspericornis, one of the most abundant freshwater copepods in Thailand, is a suitable first intermediate host for G. spinigerum. Detailed growth and developmental process of G. spinigerum larvae in $M$. aspericrnis are described. A negative relationship was observed between the mean

Table 1 Effect of initial size of EL3 on the subsequent development to AL3 in mice

\begin{tabular}{lccc}
\hline & Small EL3 & Large EL3 & $P$ value \\
\hline AL3 & & & \\
$\quad$ Recovery $($ No./mouse) & $5.67 \pm 1.21$ & $5.50 \pm 1.04$ & $>0.05$ \\
Length $(\mu \mathrm{m})$ & $3863.22 \pm 365.39$ & $3773.32 \pm 458.64$ & $>0.05$ \\
Width $(\mu \mathrm{m})$ & $330.40 \pm 27.83$ & $331.11 \pm 25.90$ & $>0.05$ \\
\hline
\end{tabular}

EL3: early $3^{\text {rd }}$ stage larvae, AL3: advanced $3^{\text {rd }}$ stage larvae 
length and width of EL3 and the density of larvae in copepods.

\section{Additional material}

Additional file 1: Video showing movement of G. spinigerum larvae in a copepod

\section{Acknowledgements}

This study was supported by grants from the Office of the Higher Education Commission; the National Science and Technology Development Agency (Discovery Based Development Grant); the Higher Education Research Promotion and National Research University Project of Thailand and Faculty of Medicine, Khon Kaen University. Penchom Janwan was supported by a CHE Ph.D. scholarship. We also thank Dr. Yukifumi NAWA for valuable comments and suggestions.

\section{Author details}

${ }^{1}$ Department of Parasitology, Faculty of Medicine, Khon Kaen University, Khon Kaen 40002, Thailand. ${ }^{2}$ Research and Diagnostic Center for Emerging Infectious Diseases, Faculty of Medicine, Khon Kaen University, Khon Kaen 40002, Thailand. ${ }^{3}$ Faculty of Medicine, Mahasarakham University, Mahasarakham 44000, Thailand.

\section{Authors' contributions}

PJ carried out the experimental studies, participated in conception and design, and acquisition of data. OS and LS participated in conception and design and acquisition of data. $\Pi$ participated in the design of the study and performed the statistical analysis. PMI carried out in revising it critically for important intellectual content and conceived of the study. WM participated in its design and coordination and helped to draft the manuscript. All authors read and approved the final manuscript.

\section{Competing interests}

The authors declare that they have no competing interests.

Received: 17 April 2011 Accepted: 27 May 2011 Published: 27 May 2011

\section{References}

1. Miyazaki I: On the genus Gnathostoma and human gnathostomiasis, with special reference to Japan. Exp Parasitol 1960, 9:338-370.

2. Daengsvang S: Gnathostomiasis in Southeast Asia. Southeast Asian J Trop Med Public Health 1981, 12:319-332.

3. Daengsvang S: A monograph on the genus Gnathostoma and gnathostomiasis in Thailand Tokyo: Southeast Asian Medical Information Center \& International Medical Foundation of Japan; 1980.

4. Van de Velde I: Revision of the African species of the genus Mesocyclops Sars, 1914 (Copepoda, Cyclopidae). Hydrobiologia 1984, 109:3-66.

5. Dussart BH, Defaye D: Répertoire mondial des Crustacés Copépodes. II. Cyclopoïdes Bordeaux: Editions du Centre National de la Recherche Scientifique; 1985

6. Rocha CEF, Botelho MJC: Maxillopoda - Copepoda, Cyclopoida. In Catalogue of Crustacea of Brazil. Edited by: Young PS. Rio de Janeiro: Museu Nacional; 1998:129-166

7. Kosiyachinda P, Bhumiratana A, Kittayapong P: Enhancement of the efficacy of a combination of Mesocyclops aspericornis and Bacillus thuringiensis var. israelensis by community-based products in controlling Aedes aegypti larvae in Thailand. Am J Trop Med Hyg 2003, 69:206-212.

8. Beaver PC, Jung RC, Cupp EW: Examination of specimen for parasites. In Clinical parasitology.. 9 edition. Edited by: Beaver PC, Jung RC, Cupp EW. Philadelphia: Lea 1984:733-758.

9. Miyazaki I: Gnathostomiasis. In An illustrated book of helminthic zoonoses. Edited by: Miyazaki I. Tokyo: International Medical Foundation of Japan; 1991:368-409.

10. Maleewong W, Sithithaworn P, Tesana S, Morakote N: Scanning electron microscopy of the early third-stage larvae of Gnathostoma spinigerum. Southeast Asian J Trop Med Public Health 1988, 19:643-647.
11. Kay BH, Cabral CP, Sleigh AC, Brown MD, Ribeiro ZM, Vasconcelos AW: Laboratory evaluation of Brazilian Mesocyclops (Copepoda: Cyclopidae) for mosquito control. J Med Entomol 1992, 29:599-602.

12. Lardeux F, Rivière F, Séchan $Y$, Kay BH: Release of Mesocyclops aspericornis (Copepoda) for control of larval Aedes polynesiensis (Diptera: Culicidae) in land crab burrows on an atoll of French Polynesia. J Med Entomol 1992, 29:571-576.

13. Nam VS, Yen NT, Holynska M, Reid JW, Kay BH: National progress in dengue vector control in Vietnam: survey for Mesocyclops (Copepoda), Micronecta (Corixidae), and fish as biological control agents. Am J Trop Med Hyg 2000, 62:5-10.

14. Almeyda-Artigas RJ, Mosqueda-Cabrera MA, Sanchez-Nunez E, SaldanaMartinez G, Hernandez-Viciconti ME, Alcolea-Herrera E: Development of Gnathostoma binucleatum Almeda-Artigas, 1991 (Nematoda: Gnathostomatidae) in its first intermediate experimental host. Res Rev Parasitol 1995, 55:189-194.

15. Mosqueda-Cabrera MA, Almeyda-Artigas RJ, Sánchez-Miranda E, CarranzaCalderón L, Sánchez-Núñez E: Description and development of the early third-stage larva of Gnathostoma turgidum Stossich, 1902 (Nematoda: Gnathostomatidae) and contributions to its life cycle. Parasitol Res 2010, 106:1321-1326.

16. Daengsvang S: An experimental study on the life cycle of Gnathostoma hispidum Fedchenko 1872 in Thailand with special reference to the incidence and some significant morphological characters of the adult and larval stages. Southeast Asian J Trop Med Public Health 1972, 3:376-389.

17. Koga M, Ishii Y, Huang WC, Xia BF: Early third-stage larvae of Gnathostoma hispidum in cyclops. Surface topography revealed by scanning electron microscopy. Parasitol Res 1987, 74:69-72.

18. Ando $\mathrm{K}$, Tanaka $\mathrm{H}$, Chinzei $\mathrm{Y}$ : Influence of temperature on development of eggs and larvae of Gnathostoma nipponicum Yamaguti 1941. Jpn J Parasitol 1989, 38:31-37.

19. Ash LR: Development of Gnathostoma procyonis Chandler, 1942, in the first and second intermediate hosts. J Parasitol 1962, 48:298-305.

20. Anderson RM, May RM: Helminth infections of humans: mathematical models, population dynamics, and control. Adv Parasitol 1985, 24:1-101.

21. Cronin JT: From population sources to sieves: the matrix alters hostparasitoid source-sink structure. Ecology 2007, 88:2966-2976.

22. Chylinski C, Boag B, Stear MJ, Cattadori IM: Effects of host characteristics and parasite intensity on growth and fecundity of Trichostrongylus retortaeformis infections in rabbits. Parasitology 2009, 136:117-123.

23. Keeney DB, Bryan-Walker K, Khan N, King TM, Poulin R: The influence of clonal diversity and intensity-dependence on trematode infections in an amphipod. Parasitology 2009, 136:339-348.

24. Cornet S: Density-dependent effects on parasite growth and parasiteinduced host immunodepression in the larval helminth Pomphorhynchus laevis. Parasitology 2011, 138:257-265

25. Shostak AW, Rosen RW, Dick TA: The use of growth curves to assess crowding effect on procercoids of the tapeworm Triaenophorus crassus in the copepod host Cyclops bicuspidatus thomasi. Can J Zool 1985, 63.2343-2351.

doi:10.1186/1756-3305-4-93

Cite this article as: Janwan et al:: Growth and development of Gnathostoma spinigerum (Nematoda: Gnathostomatidae) larvae in Mesocyclops aspericornis (Cyclopoida: Cyclopidae). Parasites \& Vectors 2011 4:93. 